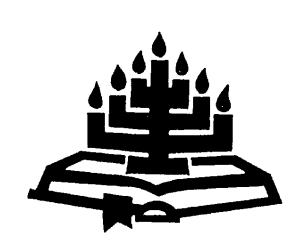

\title{
Die invloed van die Christelike geloof op die Suid-Afrikaanse samelewing
}

\author{
E. Oliver
}

Departement Christelike Spiritualiteit, Kerkgeskiedenis \& Missiologie Unisa

PRETORIA

E-pos: olivee@unisa.ac.za

\begin{abstract}
The influence of Christianity on the South African society

It was not the intention of the first Christians to change the world, but their behaviour soon influenced society. The European settlers who came to South Africa brought calvinist Christianity to the region. For the next 340 years, Christianity was a very influential force in the South African society, usually taken for granted by Christians and not allowed to be questioned, challenged or opposed by non-Christians. Today the society bears both the scars and medals of the Christian era in South African history although South Africa was never officially a Christian country. After 1994, South Africa became a neutral state, with religious freedom, and the privileged position of Christianity began to fade rapidly. More than ten years later, however, the influence that Christianity had on the country and its people is still visible. This article is an introductory investigation into the influence of Christianity on the South African society from an historical perspective.
\end{abstract}

\section{Opsomming}

Die invloed van die Christelike geloof op die Suid-Afrikaanse samelewing

Die bedoeling van die vroeë kerk was nie in die eerste plek om die politiek, ekonomie en regstelsels van die wêreld te verander nie, maar spoedig het die Christene se manier van leef die samelewing rondom hulle beïnvloed. Die Europese setlaars het die calvinistiese geloof na die suidpunt van Afrika gebring waar dit vir die volgende 340 jaar 'n leidende rol in die geskiedenis van die land gespeel het. Geen teëkanting of bevraagtekening van die bevoorregte posisie van die Christendom deur nieChristene is geduld nie en die invloed daarvan op die same- 
lewing is as vanselfsprekend aanvaar deur veral die Christelike deel van die bevolking. Vandag vertoon die samelewing sowel die medaljes as die littekens van hierdie toedrag van sake. Hoewel Suid-Afrika nooit amptelik bekend gestaan het as 'n Christelike land nie, is die geweldige invloed wat die Christendom op die land gehad het na meer as 'n dekade van godsdiensvryheid in 'n neutrale staat, steeds sigbaar. Die doel van hierdie artikel is om 'n inleidende, oorhoofse en verkennende blik te verskaf van die reikwydte en invloed wat die Christendom op die samelewing gehad het, gesien vanuit 'n historiese perspektief.

\section{Inleiding}

Hoewel die vroeë kerk se taak en roeping nie in die eerste plek was om die wêreld te verander nie, het die Christene se radikaal veranderde leefwyse spoedig 'n groot impak op die omgewing waarin hulle geleef het, gehad. Nadat die Christelike geloof tot staatsgodsdiens verklaar is, het die Christelike leefwyse die samestelling en funksionering van die samelewing bepaal. Tot onlangs nog is die Christelike geloof so vanselfsprekend as deel van die Westerse beskawing aanvaar, dat die invloed daarvan op die samelewing deur die meeste mense nie na waarde geskat is nie. Dit is eers na die draai van die eeu, miskien weens die feit dat die Christendom al hoe meer ongewens in die ekumeniese gees van die tyd geraak het, dat publikasies oor hierdie onderwerp meer algemeen geraak het (vlg. Hill, 2005; Schmidt, 2004).

Op formele en informele vlak het die Christelike geloof die samelewing beïnvloed. Dit was egter eers in die lig van die veranderings wat ná 1994 in Suid-Afrika ingetree het, dat hierdie invloede ook vir heelwat Christene duideliker en helder omlyn begin uitstaan het.

Die doel van hierdie artikel is om die reikwydte en invloed wat die Christelike godsdiens op die Suid-Afrikaanse samelewing gehad het, te probeer bepaal. Hierdie studie kan moontlik uitgebrei word deur die invloed van die Christendom op die afsonderlike bevolkingsgroepe van Suid-Afrika te ondersoek of deur gespesialiseerd te fokus op verskillende aspekte soos die invloed op politiek, ekonomie, sosiale strukture of die regstelsel. Die onderhawige artikel is egter ' $n$ inleidende, oorhoofse en verkennende studie vanuit 'n historiese perspektief.

Wanneer daar vandag gekyk word na die invloed wat die Christendom op die ontwikkeling en geskiedenis van Suid-Afrika in die laaste 
350 jaar gehad het, is die letsels wat dit gelaat het asook die medaljes wat dit verwerf het, sigbaar.

\section{Agtergrond}

Sedert kolonialisasie, tot 1994 , het die regering by tye uitsluitlik en ander kere hoofsaaklik uit Westerse Christene bestaan. Dit het tot gevolg gehad dat wetgewing daarop afgestem was om die Christelike geloof te beskerm. Gedurende die eerste 105 jaar na kolonisasie is net die Protestantse geloof aan die Kaap toegelaat en die staat het oor die burgers se godsdienstige lewe toesig gehou. In 1655 meld die sieketrooster Willem Barendts Wijland in 'n verslag dat die koloniste godsdienstig is en dat niemand sonder ' $n$ geldige verskoning mag wegbly van godsdienstige byeenkomste nie (Jooste, 1946:42). Elke aand is daar gebid en gesing en op Sondae is preke voorgelees (Jooste, 1946:43). Bywoning van alle eredienste was verpligtend en streng wette het gegeld om dié wat nie hierby ingeval het nie, te straf (Jooste, 1946:242). Die wetgewing aangaande aktiwiteite op Sondae is uitgebrei toe 'n komeet sy opwagting gemaak het en die mense gevoel het dat hulle deur die straf van die Here bedreig word (Jooste, 1946:243).

Die godsdiens van die koloniste het in die sewentiende-eeuse $\mathrm{Ne}$ derlandse calvinistiese geloof en tradisies geankerd gebly. Hoewel die eerste Lutherse kerk in 1774 in Kaapstad opgerig is, is godsdiensvryheid eers in 1778 aan hierdie sustergeloof toegestaan (Hofmeyr \& Pillay, 1994:25). Tydens die Bataafse tussenspel is wetgewing aangaande godsdiensvryheid vir die eerste keer verslap. "To read Janssen and De Mist is to read the text of the next generation of South African history" (De Kiewiet, 1941:33). Onder invloed van die liberale staatsman De Mist, word die Islam in 1804 as godsdiens erken (History of Muslims in South Africa, 2004). Hoewel die Rooms-Katolieke Kerk ook onder die wetgewing van De Mist bevoordeel is, het die eerste biskop hom eers in 1838 in die land kom vestig (Brady, 1951:116). Gedurende die negentiende eeu is Hindoeïsme na die suikerplase in Natal gebring deur die werkers wat uit die Ooste ingevoer is, nadat die slawe vrygestel is (Chidester, 1992:168). Ook ander gelowe het mettertyd hulle weg na Suid-Afrika gevind na die verslapping van die wetgewing. Die calvinistiese Protestantisme het egter steeds die grootste aanhang gehad en het saam met die Voortrekkers na die binneland versprei.

Vroeg in die twintigste eeu is Suid-Afrika in 'n Unie saamgesnoer. Die calvinistiese invloed op die regering het sterker geword en 'n hoogtepunt bereik na 1948 toe die Nasionale Party aan bewind 
gekom het. Al drie uitgawes van die Suid-Afrikaanse Grondwet wat tussen 1910 en 1983 uitgegee is, verklaar dat Christelike waardes en beskaafde norme as die eerste nasionale prioriteit beskou word.

Die Christelike kerke in Suid-Afrika was die talrykste en hulle invloed groot. Die 1904-sensus wat deur die kantoor van die Kolonies van Groot Brittanje gedoen is, bied geen verwysing na godsdiens nie (Great Britain Colonial office, 1904). Hoewel die Statistiekjaarboek van die Unie van 1913-1914 ook nie godsdienstige statistieke verskaf nie, kan die lys van huwelike wat bevestig is, wel as 'n aanduiding gebruik word van die kerkgroepe wat in die land werksaam was. Dit is opmerklik dat Islam, ander Oosterse gelowe en tradisionele Afrikagelowe nie hierby ingereken is nie, omdat hierdie huwelike nie as wettig erken is nie (Statistical Year-book of the Union of South Africa, 1915:27). Van die agtien groepe in die lys is net die Joodse geloof nie-Christelik. Daar is wel 'n klompie Christelike sektes gelys. Die Religion by geographical areas report wat op 5 Mei 2005 gepubliseer is ten opsigte van die 1996-sensus toon aan dat van die lys van 60 godsdienste en kerkgroepe wat in Suid-Afrika werksaam is, net ongeveer twaalf nie-Christelik is. Die 2001-sensus gee nie so 'n volledige uiteensetting soos die 1996-lys nie. Van die 23 gelyste godsdienste is ongeveer vyf nie aan die Christelike geloof verwant nie (South Africa, 2001).

Die 2001-sensus toon dat die getal Christene in Suid-Afrika byna $80 \%$ van die bevolking uitmaak. Daar moet egter in ag geneem word dat hierdie syfer vanuit 'n gereformeerde oogpunt as misleidend gesien kan word, onder andere aangesien die AIC (African Independent/Indigenous/Initiated/Instituted Churches; Hayes, 2006) wat die tradisionele Afrika geloof en Christendom vermeng, as deel van die Christendom gereken word. Om sake nog ingewikkelder te maak, word daar in die 2005/2006-uitgawe van die South African Christian handbook beweer dat 'n groot persentasie van Suid-Afrikaanse Christene nominale gelowiges is wie se leefwyse in 'n groot mate nie deur hulle geloof beïnvloed word nie (Erasmus, 2005:87). Ten spyte hiervan, bly dit waar dat die grootste gedeelte van die SuidAfrikaanse samelewing hulleself vandag as Christene beskou. Hierdie is 'n teenstrydigheid in die Suid-Afrikaanse samelewing wat 'n ernstige aantyging teen die Christelike geloof inhou. Hoewel die meerderheid van die bevolking Christene is, is die misdaadsyfer, padongeluksyfer en egskeidingsyfer van die hoogste in die wêreld. Sedert 1997 is ook meer as 650000 wettige aborsies uitgevoer (News24, 2007). Die vraag kan gevra word of die Christelike geloof werklik enige invloed op die daaglikse lewe van die bevolking het. 
Hoewel hierdie etiese vraag beantwoord moet word, is die doel van hierdie artikel histories van aard en daar word dus in die volgende deel op die formele en informele invloede wat die Christendom op die samelewing gehad het, gefokus.

\section{Formele invloede}

Suid-Afrika het nooit amptelik as 'n Christelike staat bekend gestaan nie, maar die Christelike karakter van die samelewing was oral sigbaar. Die Christelike geloof, en veral die calvinistiese interpretasie daarvan, het 'n bepalende rol in die geskiedenis en ontwikkeling van die land gespeel. Op politieke gebied het die Christelike geloof sy stempel afgedruk deur onder andere die regeringsbeleid en die nasionale simboliek. As praktiese voorbeeld kan die daaglikse opening van die Volksraad en Parlement met gebed genoem word (Coetzee, 1945:369).

Die Romeins-Hollandse regstelsel wat in die Nederlande gebruik is, is deur die Europese koloniste na Suid-Afrika gebring waar dit die fondasie van wetgewing gevorm het vir die volgende drie eeue saam met die Engelse gemenereg wat na die Engelse kolonisasie bygevoeg is. Die gebruik om getuies in Suid-Afrikaanse howe te vra om 'n Christelike eed af te lê, is 'n bewys dat die juridiese stelsel tot op grondvlak deur die Christendom beïnvloed is (Hofmeyr, 1913:3).

Die invloed van die Christelike geloof op die ekonomie kan gesien word in wetgewing ten opsigte van besigheidsure en Sondagheiliging. Aan die ander kant is ekonomiese faktore toegelaat om in sommige gevalle die Christelike waardes eenkant te skuif, soos gesien kan word in wetgewing oor fabrieke, myne en dobbelary.

Dr. D.F. Malan, die latere staatspresident, het met sy "ons kerk is nasionaal"-uitspraak in 1915 reeds die invloed van die Protestantse kerk op sosiale strukture duidelik gemaak (Giliomee, 2003:385).

\subsection{Wetgewing}

Veel groter as die wette wat deur die staat ingestel is, was die invloed van die algemene Christelik-morele opvoeding wat openbare optrede in die agtiende- en negentiende-eeuse Suid-Afrikaanse samelewing bepaal het. In die Zuid-Afrikaansche Republiek (ZAR) was dit so opmerklik dat daaroor geskryf is:

The laws of the Transvaal (1865) were upon the whole as good as those of any other country, but for want of a police it was impossible to enforce justice in all cases, yet great crimes were 
exceptionally rare, for nowhere in the world was the moral law of greater force than among the farmers of the South African Republic. (Nixon, 1880:208.)

Tog is heelwat wetgewing ingestel wat die Christelike geloof direk of indirek beskerm en bevoordeel het.

\subsubsection{Wetgewing ten opsigte van Sondagheiliging}

Keiser Konstantyn het in 321 n.C. die Sondag tot amptelike rusdag verklaar (Biblical history timeline) en sedertdien het Christene reg oor die wêreld die Ou-Testamentiese wet van geen werk op die Sabbat nie, na hierdie dag oorgedra.

Menslike aktiwiteite op Sondae was in Suid-Afrika 'n deurlopende bron van irritasie. Tydens die eerste sinodesitting in 1824 is kommer uitgespreek oor die onnodige koop en verkoop van goedere, die lawaai in die strate, die spel, dobbel en oop kroeë op Sondae (Jooste, 1946:242). In 1828 is 'n wet goedgekeur wat die Superintendent van die polisie opdrag gegee het om toe te sien dat geen handel op Sondae plaasvind nie en dat die plekke van ontspanning gesluit bly (Jooste, 1946:27). Die wet van 1837 verbied "veldwerk" en die hantering van vuurwapens op Sondae (Jooste, 1946:248).

Rosslee (1955:16-22) gee 'n goeie opsomming van die wette oor Sondagheiliging in die latere vier provinsies van Suid-Afrika. Die Provinsiale (Hoof)wette dateer uit die negentiende eeu. Hierdie wette is aangevul met die Provinsiale Ordonnansies wat dinge soos winkelure en handel bepaal, terwyl die Uniale Wette te doen het met Sondagarbeid op die myne, in fabrieke en bouwerk asook werk in winkels en kantore. Die wetgewing verskil van provinsie tot provinsie. As voorbeeld kan genoem word dat transportryery op Sondae in die Transvaal verbied is, terwyl daar niks oor hierdie saak in die ander drie provinsies se wetgewing gemeld word nie (Hofmeyr, 1913:6).

$\mathrm{Na}$ die ontdekking van die minerale rykdomme, is die wette aangepas om arbeid op Sondae in myne en fabrieke toe te laat (vgl. Rosslee, 1955). Wanneer die wette oor Sondagheiliging wat teen die einde van die negentiende eeu gegeld het, vergelyk word met die "geen handel en geen veldwerk"-wet van ongeveer 50 jaar vroeër, is dit baie duidelik dat die ekonomie, en nie die Christelike geloof nie, 'n bepalende rol gespeel het in die opstel daarvan. Nog 'n voorbeeld wat die motivering agter die wette onder verdenking bring, word in die Vrystaatse Sondagwetgewing gesien: Aan die een kant is daar streng wetgewing wat selfs visvang op Sondae verbied, 
maar aan die ander kant mag daar op Sondae in winkels gewerk word solank die deure gesluit bly (Rosslee, 1955:18).

Tot en met die tagtigerjare van die twintigste eeu het streng wetgewing ten opsigte van winkelure, die verkoop van drank en plekke van vermaak op Sondae gegeld. Bioskope is sedert 1993 toegelaat om films op Sondae te vertoon (Sooka, 1993:86). 'n Versoek om georganiseerde Sondagsport toe te laat, is aanvanklik sterk teëgestaan (vgl. Van der Vyver, s.a.:1; Van Wyk, 1981:1). Vandag het hierdie wette drasties verander. Sondagsport is 'n algemene praktyk en die tradisionele gebruik van Christene om te weier om enige vorm van handel op Sondae te bedryf, het feitlik heeltemal verdwyn.

\subsubsection{Wetgewing ten opsigte van openbare vakansiedae}

In Suid-Afrika is Kersfees en Paasfees tradisioneel as openbare vakansiedae gereken en die Christelike kalender het 'n bepalende rol gespeel in die voor-1994-dagboeke. Die demokratiese regering het egter die klem op die Christelike feesdae in 'n mate laat vervaag deur Hemelvaartdag as vakansiedag weg te neem. Geloftedag het in die lig van die politieke geladenheid daarvan 'n naamsverandering ondergaan, maar steeds deel van die openbare vakansiedae gebly. Christene het hierdie twee dae tradisioneel as Sondae beskou, met geen werk, sport of handel wat bedryf is nie (Booyens, 1970:33).

\subsubsection{Wetgewing ten opsigte van onderwys}

Voordat die Nederlandse setlaars na Suid-Afrika gekom het, was die onderwys in Nederland geskoei op die Christelik-Nasionale model wat as teenvoeter vir neutrale staatsonderwys moes dien (Van der Kooi, 1999). Die Christelik-Nasionale Onderwysmodel is saam met die Protestantse lewensbeskouing van die eerste setlaars in die geskiedenis van Suid-Afrika ingedra. Daar is algemeen aanvaar dat die Christelike opvoeding die bril moes verskaf waardeur die opkomende geslag die wêreld asook hulle eie plek en rol in die samelewing moes sien (Engelbrecht, 1980:9). Godsdiensonderrig aan die jeug moes deur logika en geskiedkundige voorbeelde bewys dat dit in werklikheid nie gaan oor wat iemand weet of wat hy besit nie, maar dat wat hy is, bepaal word deur wat hy glo (Geyser, 1980:23). Hierdie siening oor Christelike opvoeding en onderwys loop soos 'n goue draad deur die geskiedenis van Suid-Afrika.

Onder die invloed van J.A. de Mist is gepoog om, in ooreenstemming met die idees van die Franse rewolusie, die wêreldbeeld van die Afrikaners te verander, deur neutrale skole en godsdienstige 
verdraagsaamheid in te stel. Hierdie beleid is verder gevoer deur die Engelse regering. Hoewel die godsdiensvryheid wat aan ander denominasies gegee is, nie geweldige opslae gemaak het nie, het die veranderde onderwysbeleid spoedig tot radikale verset onder Christene gelei. Christelik-Nasionale Onderwys (CNO) is ingestel om die Afrikaner se taal, geloof en kultuur (en dus ook die Afrikaner se siening oor Christendom) te beskerm (Cross, 1999:13). Na die Tweede Anglo-Boereoorlog is weer op die CNO teruggeval om die Christelike waardes en fondasies te versterk (Barnard, 1935:79,80).

Die invloed van die Christelike opvoeding het tot op tersiêre vlak gestrek. Die voormalige Potchefstroomse Universiteit vir Christelike Hoër Onderwys (PU vir CHO) het uit die Teologiese Skool van die Gereformeerde Kerke in Suid-Afrika (GKSA), gestig op 29 November 1869 te Burgersdorp, ontstaan. In 1905 is die Teologiese Skool na Potchefstroom verskuif. In 1919 kry "Het Potchefstroom Universiteitskollege voor Christelike Hooger Onderwijs" sy beslag. In 1951 is die PUK erken as 'n selfstandige Universiteit wat tot onlangs bekend gestaan het as die Potchefstroomse Universiteit vir Christelike Hoër Onderwys (PU vir $\mathrm{CHO}$ ).

Die ontsporing van die CNO het begin toe die Afrikaans-Christelike onderwysstelsel ook na ander bevolkingsgroepe uitgebrei is. $\mathrm{Na}$ 1948 is Afrikaans as enigste onderrigtaal in al die provinsies, met die uitsondering van Natal, aanvaar (Giliomee, 2003:490). Dit het tot groot ongelukkigheid en opstand aanleiding gegee. Die demokratiese regering het na 1994 besluit om Christelike onderwys te vervang met religieuse onderwys waarin die Christelike geloof sy bevoorregte posisie moes prysgee en gelykgestel is aan ander gelowe.

\subsubsection{Wetgewing ten opsigte van natuurbewaring}

Hill (2005:69) is van mening dat Christene toenemend bewus raak van hulle verantwoordelikheid teenoor die omgewing. Hy sê daar is 'n groeiende beweging binne die Christendom om gelowiges ekologies sensitief te maak en om daadwerklike pogings aan te wend om die natuur te bewaar.

Die geskiedenis van natuurbewaring in Suid-Afrika is ongelukkig nie so positief en Christelik gefundeerd soos dikwels aan die publiek voorgehou word nie. Carruthers (1995:8) wys daarop dat die eerste bewaringswetgewing reeds in 1654 in die Kaap uitgereik is en dat ander wette wat daarop gemik was om die wildlewe te beskerm periodiek daarop gevolg het. In 1822 is die Britse model van 
bewaringswetgewing in die Kaap ingevoer. Hierdie wetgewing het voorsiening gemaak vir spesiale beskerming van olifante, seekoeie en bontebokke, 'n geslote jagseisoen vir sekere wildsoorte, 'n verbod op die doodmaak van onvolwasse wild, en 'n miniatuur wildreservaat naby Malmesbury (Carruthers, 1995:17).

Ongelukkig was die wetgewing nie geslaagd nie. Bloubokkies en kwaggas is heeltemal uitgewis en ander spesies se getalle het drasties afgeneem. Afrikaners het die oorbenutting van natuurlike hulpbronne soos wilde diere, nooit as 'n ernstige kriminele oortreding gesien nie. Hulle godsdiens was hoofsaaklik geskoei op die Ou Testament (vgl. Calpin, 1944:17; Rose, 1902:10,11; Akenson, 1992:61) waarin wild geen spesiale vermelding kry nie. Calvinisme beklemtoon die heerskappy van die mens oor die natuur. Dit is selfs as immoreel en onpatrioties gesien om nie deel te neem aan die jag van wilde diere nie, omdat dit as voordelig vir die hele bevolking beskou is. Jag het die land "skoongemaak" sodat landbou bedryf kon word (Carruthers, 1995:18,19). In sy Memoirs het Paul Kruger (1902:18) gesê dat elke Boer 'n aktiewe rol in hierdie werk gespeel het, en dat die jeug 'n groot bydrae gelewer het om die land bewoonbaar te maak. Die oorlog teen die wilde diere van Afrika deur al wat leef het byna onmiddellike gevolge gehad en teen ongeveer 1850 was die groot wildtroppe aansienlik uitgedun (Carruthers, 1995:21).

In 1846 is vir die eerste keer melding gemaak van die noodsaaklikheid om 'n deel van Afrika se natuurskoon vir die nageslag te bewaar. Daar is besef dat die pas waarteen die diere verdwyn tot gevolg sou hê dat daar spoedig nie veel sou oorbly om te bewaar nie. Nogtans is daar nie veel aan die saak gedoen nie. Tot ongeveer 1858 is die mening onder veral wit jagters gehuldig dat die wildtroppe in Transvaal onuitputbaar was (Carruthers, 1995:22).

Tussen 1858 en 1881 het 'n gesindheidsverandering teenoor die uitroei van die wildlewe in Transvaal begin posvat (Carruthers, 1995:43). Op openbare aandrang is die Pongolawildreservaat in 1894 gestig en die Sabiereservaat in 1898. Eers in 1926 is die Nasionale Parkewet deur die parlement goedgekeur. In dieselfde jaar smelt die Sabie- en Shingwedziparke saam om die Kruger Nasionale Park te vorm - die eerste Nasionale Park in die Unie van Suid-Afrika (Carruthers, 1995:150). Vandag is die 21 Nasionale Parke in Suid-Afrika van die grootste toeriste-aantreklikhede in ons land. 


\subsection{Regeringsbeleid}

Die grootste enkele negatiewe invloed van die Christendom op die Suid-Afrikaanse samelewing is waarskynlik die twintigste-eeuse apartheidsbeleid. Kerkleiers het die beleid ondersteun en selfs gevra dat dit geïmplementeer word (South Africa, 1950:cols 4141-4142). Die Algemene Sinode van die NG Kerk het 'n verslag oor rasseaangeleenthede waarin Skriftuurlike begronding vir die apartheidsbeleid gegee is, in 1974 aanvaar (NG Kerk, 1975:100). Verder het nie een van die drie Afrikaanse susterkerke hulle voor 1986 teen die apartheidsbeleid uitgespreek nie (Giliomee, 2003:528). Net soos die kruistogte in die ná 20/20-visie deur heelwat Christene veroordeel word, en verskoning gevra is deur gelowiges in 1996 (Answering Islam, 1999-2008), is daar ook deur talle Suid-Afrikaners verskoning gevra vir apartheid en die gevolge daarvan (Truth and reconciliation commission, 1998).

\subsection{Nasionale simbole}

Dit wil voorkom asof die karakter van 'n volk in sy nasionale simbole weerspieël word. Sulke simbole word in verskillende vorms en op verskillende plekke aangetref: op munte, banknote, posseëls, wapens, leuses, medaljes, vlae, monumente, strukture en selfs persone wat nasionale ikone word (Jenkins, 2004:1).

\subsubsection{Suid-Afrika se leuse}

Die aktiewe geloofslewe van en gehegtheid aan die Nederlandse Bybel deur die Afrikaanssprekende deel van die bevolking het 'n direkte invloed op die keuse van die land se leuse gehad. Saam met die Hollandse Bybels het die spreuk Eendraght maeckt maght na Suid-Afrika gekom. Hierdie leuse is 'n vertaling van die Latynse Concordia res parvae crescunt. Dit was saam met die Nederlandse leeu in die ou Statebybel afgedruk en daarom aan die Afrikaners goed bekend (Pama, 1960:5). Reeds in 1839 het hierdie leuse vir Andries Pretorius as slagspreuk gedien en toe die Volksraad van die ZAR in 1858 die Vierkleur as vlag aanvaar het, is aanvanklik besluit om die leuse op die vlag aan te bring. Hoewel dit nooit gebeur het nie, is die leuse as deel van die landswapen behou (Pama, 1960:5). Met Uniewording in 1910 moes die Nederlandse leuse weer plek maak vir ' $n$ Latynse vertaling om die Engelse deel van die bevolking te akkommodeer en die oorspronklike Concordia res pavae crescunt is vervang met Ex unitate vires (Pama, 1965:25). Hierdie leuse is in 2000 vervang met die nuwe landswapen en leuse. 


\subsubsection{Suid-Afrika se volksliedere}

Sowel die ou Transvaalse as Vrystaatse volksliedere verwys na die volk se Christelike geloof. Die derde strofe van die Transvaalse volkslied (Kent gij dat volk) wat in 1875 deur Catharina F. van Rees gedig is, verwys na God as die Een wat uitkoms gee en wat geloof en geprys moet word (FAK, blêrkas, 2006, 26). Strofes twee, drie, vier en vyf van die Vrystaatse Volkslied (Heft, Burgers, 't lied der vrijheid aan) wat deur H.A.L. Hamelberg in 1865 gedig is (Pama, 1960:19), verwys na die godsdienstige karakter en geloof van die Vrystaters (FAK blêrkas, 2006, 29).

Die Stem van Suid-Afrika is in 1918 deur die Afrikaanse skrywer en digter C.J. Langenhoven gedig. Die gedig het eers net drie strofes gehad, maar nadat 'n koerantleser die aandag daarop gevestig het dat die Afrikanervolk se geloof deel van sy karakter is, is die vierde strofe bygevoeg (Pama, 1960:22, 23). Hierdie volkslied is in 1928 vir die eerste keer in die openbaar gesing en het veral na die 1938Voortrekker Eeufees gewild geraak (Pama, 1960:21). Dit het eers in 1957 amptelik die volkslied geword wat die Transvaalse en Vrystaatse volksliedere en die Engelse, God save the queen, vervang het (National anthem, 2007).

Nkosi Sikelel' iAfrika is in 1897 deur Enoch Sontonga, 'n onderwyser by die Metodiste sendingskool in Johannesburg, gedig. Die eerste strofe is oorspronklik in Xhosa geskryf as 'n gewyde lied. In 1927 is nog sewe verse deur die digter Samuel Mqhayi bygevoeg. Die lied het 'n gewilde kerksangstuk geword, maar dit is ook as volkslied tydens politieke byeenkomste (ANC, 1996) gebruik.

'n Proklamasie deur die Staatspresident op 20 April 1994 het bepaal dat sowel Die Stem as Nkosi Sikelel' iAfrika voortaan as die volkslied van Suid-Afrika bekend sou staan. In 1996 is 'n verkorte gekombineerde weergawe as die nuwe Nasionale volkslied bekendgestel (ANC, 1996).

Hoewel die Suid-Afrikaanse volkslied dikwels verander het, is dit opmerklik dat in elkeen van hierdie liedere God as Albeskikker en Heer erken en geprys word. Die volkslied (in al sy vorms) is 'n uitbeelding van die volk se Christelike geloof.

\subsubsection{Suid-Afrikaanse munte}

Vir byna 'n eeu het die Suid-Afrikaanse geldstelsel die getuienis van die Christelike volkskarakter uitgedra (Nel, 2002). Die gedagte om mossies op die kleinste munt aan te bring, het tydens die Anglo- 
Boereoorlog op Bethulie in die konsentrasiekamp ontstaan. 'n Groep vroue het as leuse en inspirasie die Bybelteks in Mattheus 10:29 gekies. Na afloop van die oorlog het hierdie vroue hulle daarvoor beywer dat die mossies op die land se kleinste munt afgebeeld moet word. Die Suid-Afrikaanse Munt het in 1923 tot stand gekom en twee mossies is op die kwartpennie aangebring. In 1961 het SuidAfrika na ' $n$ desimale geldstelsel oorgeskakel. Die mossie-ontwerp is op die nuwe halfsentstuk oorgedra. In 1991 het daar weer 'n nuwe muntreeks verskyn. Die halfsent het verdwyn, maar die mossies is op die 1c behou. Met die wegdoen van die 1c- en 2c-munte, het die mossies en hulle Bybelse betekenis uit die Suid-Afrikaanse geldstelsel verdwyn.

Suid-Afrika was die enigste land ter wêreld wat mossies op muntstukke afgebeeld het. Interessant genoeg, word die slagspreuk Soli Deo Gloria steeds op die R1-muntstuk se voorkant afgebeeld.

\subsubsection{Suid-Afrikaanse posseëls}

Die Christelike volkskarakter kan ook gesien word in die SuidAfrikaanse filatelie. Dineo Poo (2006) van die Suid-Afrikaanse Poskantoor het bevestig dat daar deur die jare 'n besonder groot aantal seëls met 'n Christelike inslag gedruk is. Bybelseëls is in 1970 en 1987 uitgegee. Die Hervorming se 450e herdenking is ook op ons posseëls weerspieël. Elke jaar is ook 'n stel Kersfeesseëls uitgegee. "Ongelukkig is die Kersfeesseëls wat in 2006 uitgegee word die laaste, tensy daar 'n beleidsverandering kom." (Poo, 2006.)

\section{Informele invloede}

Die sosiale leefwêreld van die Afrikaners (veral die blankes en kleurlinge, maar ook tot 'n mate die swart bevolking wat deur middel van sendingaksie aan die Christendom blootgestel is) is deur die Christelike leefwyse beïnvloed. Die Christelike invloed is veral sigbaar in die taal en kultuur van Afrikaanssprekendes. Die Afrikaanse taal was tot 'n paar dekades gelede nog deurspek met gesegdes en vaste uitdrukkings uit die Bybel. Die rede hiervoor was dat die mense wat Afrikaans as moedertaal gepraat het, die inhoud van die Bybel baie goed geken het en dit direk op hulle daaglikse lewens van toepassing gemaak het (Oliver, 2005:43). As praktiese voorbeeld waar geloof die handelinge van mense op sosiale vlak beïnvloed het, kan begrafnisgebruike genoem word. Grafte word tradisioneel oos-wes uitgelê in afwagting op die wederkoms van Christus, terwyl verassings tradisioneel nie groot aftrek gekry het 
nie, omdat dit as strydig met die Christelike geloof gesien is (Oliver, 2007:558).

\subsection{Wêreldbeeld en waardestelsel}

Die Christelike wêreldbeeld, veral die konserwatiewe calvinistiese vorm daarvan, het die Suid-Afrikaanse geskiedenis oorheers tot aan die einde van die twintigste eeu. Spore van die Christelike geloof was oral in die samelewing te sien. Politieke vergaderings, veevendusies, skoolfunksies, sportbyeenkomste, munisipale vergaderings en kultuurorganisasies se byeenkomste is met Skriflesing en gebed (en gewoonlik ook gewyde sang) geopen en met gebed afgesluit (De Vaal, 1939:27). Daar is eenvoudig aanvaar dat die mense teenwoordig almal of oorwegend Christene is en dat die Here as Albeskikker in alle situasies erken en vereer behoort te word.

Die Reformatore se beklemtoning van die feit dat elke mens die Bybel in sy eie taal moet kan lees, het 'n groot invloed gehad op die feit dat Afrikaners dwarsdeur die geskiedenis groot klem daarop gelê het dat hulle kinders moet kan lees en skryf (Kruger, 1902:12). Dit is dus 'n ernstige aantyging teen die Suid-Afrikaanse Christendom dat die huidige volwasse ongeletterdheidsyfer so hoog is. Volgens die 2001-sensus word 33,9\% volwasse Suid-Afrikaners as ongeletterd gereken (Harley, 2004). In aansluiting hierby is dit ontstellend dat daar in 2000 slegs Bybels beskikbaar was in 19 van die 32 tale wat in Suid-Afrika gepraat word, en die Jesusfilm is in slegs agtien van hierdie tale vertaal (Johnstone, et al. 2001:576).

Tradisioneel was die egskeidingsyfer in Suid-Afrika baie laag omdat egskeiding in direkte teenstelling met die Christelike geloof gesien is (vgl. Grobbelaar, 1974:159). In 1915 was daar 133 egskeidings onder die blanke bevolking, en geen statistieke van ander bevolkingsgroepe word aangedui nie (South Africa marriages and divorces report, 1915). In 2004 is 12437 blanke egpare geskei. Hierdie getal is die hoogste van al die bevolkingsgroepe (Statistics South Africa, 2004). Anthony van Tonder (Greef, 2006) van die Family life Change Centre beweer dat $67 \%$ van alle Christelike huwelike wat in Suid-Afrika gesluit word, verbrokkel en in die egskeidingshof eindig. Dit lyk dus asof die Christelike beginsel in hierdie geval onder die realiteite van die moderne samelewing buig.

Christene heg 'n hoë waarde aan die menslike lewe. Aan die een kant is dit waarom Christene so gekant is teen die afskaffing van die doodstraf, wat volgens die Bybel die prys is wat vir moord betaal 
moet word. Talle Christene is oortuig dat die afskaffing van die doodstraf direk verantwoordelik is vir die hoë misdaadsyfer in die land (vgl. Nduru, 2006). Aan die ander kant is dit ook deels die rede waarom selfmoord in Suid-Afrika deur die deursnee Christene as onaanvaarbaar beskou word (Geldenhuys, 2006; Vorster, 2006).

Christene is oor die algemeen teen dobbelary gekant (Van Wyk, 1980). Voordat die Nasionale Dobbelwet van 1996 ingevoer is, was dobbelary in Suid-Afrika op 'n beperkte skaal bedryf, (bv. casino's, perderesies en bonusobligasies) maar dit was egter nie slegs nieChristene wat aan hierdie bedrywighede deelgeneem het nie.

\subsection{Taal en naamgewing}

Hoewel Afrikaans een van die jongste tale ter wêreld is, is die tradisionele vorm deurspek met idiome en vaste uitdrukkings uit die Bybel (vgl. Oliver, 1998; De Villiers, 1988). Selfs plek- en plaasname is eenvoudig uit die Bybel oorgeneem (bv. Nylstroom, Elim, Bethlehem, Mara, Benoni, Hermon, Nebo, Eden, Abel, Hebron, Jericho, Jerusalem, Ebenhaeser, Libanon, Dan, Nasaret, Nylrivier, Jordaanrivier, ensovoorts). Die Engelse skrywer, Lawrence Green, is van mening "dat mens nêrens buite Palestina soveel plekke en dorpe met Bybelname kry as in Suid-Afrika nie" (Jordaan, 2004:90).

Die gebruik om 'n (nuwe) naam aan iemand te gee wanneer die persoon gedoop word, is baie oud. Dit het ook deel geword van die Christelike gebruike in Suid-Afrika. Ons praat vandag nog van doopname. Hoewel hierdie gebruik positief deur die meeste blankes en kleurlinge gesien word, het dit in die laaste klompie jare gemoedere onder die swart bevolking laat opvlam. Oral in Afrika is hewig debat gevoer oor die doopname of sogenaamde Christian names wat aan Afrikane gegee is wanneer hulle gedoop is (Ngandeu, 2000; BBC News: Africa, 2003; Life in America, 2000).

Saam met die verwyt oor die Christelike name is daar ook toenemende ontevredenheid oor die Westerse kultuur wat saam met die Christelike geloof op veral die swart bevolking van Suid-Afrika afgedwing is. Dit is as gevolg van die feit dat kultuur en geloof so versmelt is dat daar nie onderskeid getref word tussen die twee nie. Westerse kleredrag, eetgewoontes, behuising, beroepe, taalgebruik, seremonies (soos huwelike) en medikasie het die plek van tradisionele sisteme en gebruike ingeneem. Hoewel baie van hierdie dinge in die Afrika-Renaissance herleef, voel mense dat hulle noue verbintenis met hul eie kultuur nie volkome herstel kan word na (gedwonge) blootstelling aan die Christelike, Westerse leefwyse nie. 
Tydens die Afrika-Renaissance Konferensie in 1999 het Ntulli dit so gestel: "The West has shaped our thoughts and now controls our minds." (Swaraj Foundation, 2001.)

\subsection{Geboue en monumente}

Dorpe het dikwels ontstaan rondom plekke wat as kerkplase gebruik is. Pretoria dien hier as voorbeeld (Labuschagne). Dorpstigting het plaasgevind op die twee plase Elandspoort en Daspoort waar gereeld kerk gehou is. Die eerste gebou wat gewoonlik op 'n dorp opgerig is, was die kerk (Stuart, 1854:213). Hierdie kerke was, in ooreenstemming met die konserwatiewe calvinisme, groot, eenvoudig, sonder versierings en is net vir eredienste gebruik. Wanneer die Suid-Afrikaanse kerkgeboue met Europese eweknieë vergelyk word, vertoon hulle leeg en kaal sonder die rykdom van beelde en afbeeldings en ander versierings. Tradisioneel het calviniste geglo dat Calvyn teen veral visuele kuns in die kerke was, omdat dit mense kan verlei om die tien gebooie te oortree. Hoewel hierdie siening onlangs deur Joby (2007) bevraagteken is, word dit steeds deur die meerderheid calvinistiese Christene in Suid-Afrika gehuldig. Die kerke het gewoonlik in die sentrum van die dorp gestaan (Bryce, 1900:320). Vandag is die kerke nog opmerklik in die ou dorpe wat deur Christene gestig is, soos Potchefstroom, Lydenburg, Rustenburg, Pretoria en Krugersdorp, terwyl dorpe wat deur goudsoekers gestig is soos Pelgrimsrus en Johannesburg (Langlaagte, Fordsburg en Braamfontein) geen kerke en kerkpleine in die middel van die ou dorpsgebied het nie (Coetzee, 1945:422).

Die altaarvorm en -idee (Pretorius, 2008) van die Voortrekkermonument in Pretoria dien as ' $\mathrm{n}$ voorbeeld van die klem wat veral die Afrikaners op die Ou-Testamentiese deel van hulle geloof gelê het (vgl. Calpin, 1944:17; Rose, 1902:10, 11; Akenson, 1992:61).

\subsection{Christelike welsynswerk}

Christelike welsynwerk het deur die eeue 'n geweldige invloed op die samelewing gehad. In die vierde eeu het Keiser Flavius Claudius Julianus gesê dat die feit dat Christene siekes versorg en dooies begrawe hulle onderskei het van die heidene en ook dat dit as 'n sterk aantrekkingskrag gedien het tot die Christelike geloof (Ansgar, 2002:68). Daar is vandag baie welsynsorganisasies in Suid-Afrika wat meestal deur Christene en grootliks deur vrywilligers bedryf word tot voordeel van die hele gemeenskap (vgl. Symington, 2005). Die dienste wat verskaf word sluit onder meer in kindersorg, bejaardesorg, gemeenskapsdienste, berading, siekesorg, middelafhanklik- 
heid, VIGS, swangerskap, versorging van gestremdes, gevangenes en straatkinders (NG Kerk, 2006). Indien daar 'n maatskaplike behoefte ontstaan, is die kans goed dat 'n Christelike organisasie met die hulp van vrywilligers, hetsy plaaslik of nasionaal, spoedig in hierdie behoefte sal probeer voorsien. Die huidige situasie rondom MIV en VIGS waar talle kinders wees óf onversorg gelaat word wanneer ouers sterf, óf te siek is om te werk, word in 'n groot mate deur Christelike organisasies en vrywilligers hanteer (Symington, 2005:269, 270). Christelike welsynswerk in Suid-Afrika het deur die jare in 'n groot mate die druk vir hierdie dienste op die skouers van die regering verlig.

\subsection{Die Christelike kerk}

Hoewel dit duidelik is dat die Christelike geloof sedert die aankoms van die eerste Europeërs in Suid-Afrika 'n belangrike rol in die geskiedenis en ontwikkeling van die land gespeel het, is dit ook waar dat die Christelike kerk op amptelike vlak nie 'n beduidende invloed uitgeoefen het nie. Die rede hiervoor is duidelik sigbaar wanneer daar na die geskiedenis gekyk word. Politieke en dogmatiese geskille het die kerk verdeel (Schutte, 1943:30). Op 'n stadium was die onenigheid so erg dat mense bereid was om hulle standpunt met geweld en oorlog te verdedig (Pont, 1968:197). Ten spyte van die samehorigheidsgevoel wat Afrikaners na die Eerste Vryheidsoorlog saamgebind het en 'n poging tot kerkeenheid tot gevolg gehad het, het versplintering spoedig weer ingetree en het die voortgaande geskille tot verdere afskeidings gelei, ook in die twintigste eeu.

Meningsverskil het hoogty gevier oor sake soos die vrou in die amp, die sing van geestelike liedere, sendingbeleid, die gebruik van die kinderbybel en afsonderlike kinderdienste, deelname aan dobbelary (soos die bonusobligasies). Die korrekte weergawe van die naam van die oorspronklike kerk, sowel as talle ander kwessies het ook daartoe bygedra dat die kerke mekaar nie kon vind om uit een mond te praat en riglyne te gee oor belangrike geloofskwessies nie.

Selfs binne die verskillende kerke was en is daar ernstige verdeeldheid. Die NG Kerkfamilie bestaan uit groepe wat sukkel om hande te vat en dit tot op grondvlak deur te voer. By die ander susterkerke is die lyne van skeiding tussen die moeder- en dogterkerke stewig in plek.

Sommige van die Engelse kerke het ernstige verdeeldheid ervaar toe die AIC-genootskappe weggebreek het van die moederkerke, 
omdat gevoel is dat hulle onderdruk en oorheers word en dat die moederkerke te voorskrywend optree. Teen 2000 het $32 \%$ van die swart Christelike bevolking aan die AIC behoort (Johnstone, et al. 2001:577).

Daar is 'n groot aantal denominasies in Suid-Afrika: 185 Protestantse kerke en 4589 onafhanklike kerke (Johnstone et al., 2001: 577). Die Suid-Afrikaanse Raad van Kerke bestaan uit slegs 26 lede (SACC, 2001). Die verskillende kerkgenootskappe onttrek na willekeur uit die SARK of weier om daarby aan te sluit. Daar is dus geen organisasie wat daarin kan slaag om as 'n oorkoepelende liggaam en spreekbuis vir die Suid-Afrikaanse kerke te dien nie.

Die kerklike verdeeldheid en versplintering is waarskynlik een van die hoofoorsake dat die calvinistiese Protestante nooit in staat was om 'n verenigde front te vorm wat uitsprake kon maak of riglyne kon bied op krisisse in tye van nood of verwarring nie. So is die kans grootliks verbeur om op 'n deurlopende basis die stem van die evangelie sterk en beslis deel van die land se bepalende invloede te maak, en om op alle gebiede waardevolle insette te lewer en as korrigeerder te dien wanneer daar polities, ekonomies of maatskaplik misgetas is.

\section{Slot}

Vir meer as drie eeue is die voorrang wat die Christelike geloof geniet het as vanselfsprekend aanvaar deur veral die Christelike deel van die samelewing. Hierdie invloed is deur die jare nie bevraagteken of as 'n bron vir navorsing beskou nie, maar bloot as 'n gegewe aanvaar. Hoewel dit wil voorkom asof die gewildheid van die Christelike geloof aan die taan is en die invloed daarvan daagliks kleiner word as gevolg van nuwe wetgewing en 'n veranderde leefstyl, is die invloed van die Christendom op die Suid-Afrikaanse samelewing in sekere opsigte egter steeds sigbaar.

Die oorsprong van sommige van die nasionale simbole van SuidAfrika kan teruggespoor word tot by die calvinistiese geloof wat saam met Jan van Riebeeck na Suid-Afrika gekom het en as grondslag vir die politieke lewe gedien het tot laat in die twintigste eeu. Die invloed en reikwydte van Christelike welsynsorganisasies en ook die werk wat deur Christelike vrywillige werkers verrig word, is 'n uitsonderlike prestasie. Die feit dat die Christelike kerk op die voorpunt van hulpverlening is, dien as bewys dat talle Christene hulle roeping en taak om hier op aarde Jesus se hande en voete te wees, daagliks uitleef. 
Onder die vaandel van Christenskap is egter ook baie gruwels bedryf. Die uitwissing van spesies en die verwoesting van die natuurlewe deur Christene kan vanuit geen hoek goedgepraat of as minder ernstig afgemaak word nie. Dit is jammer dat wetgewing ingespan moes word om Christene op te voed ten opsigte van hulle verantwoordelikheid en die uitlewing van hulle geloof oor sake soos natuurbewaring, Sondagheiliging en dobbelary. Ongelukkig het die na-binne-gekeerde fokus van heelwat van die blankes se siening oor die Christelike geloof deur die jare aanleiding gegee tot talle foute en mistastings met tragiese gevolge. Die beeld en geloofwaardigheid van die Christelike geloof in die algemeen is hierdeur ernstig geskaad. Die letsels gelaat deur apartheid en die gepaardgaande wetgewing, is na meer as 'n dekade van demokrasie steeds nie vergete of genees nie.

Aantygings word teen die Christendom ingebring dat gelowiges hulle roeping en taak in die wêreld versuim het. Dit het 'n groot aantal Suid-Afrikaners ongeletterd gelaat en daarmee saam ook die geleentheid ontneem om self die evangelie te kan lees en dit aan ander te leer. Die hoë egskeiding- en aborsiesyfers kan die vermoede bevestig dat die persentasie nominale Christene in SuidAfrika in werklikheid baie hoog is en die invloed van die Christelike geloof radikaal besig is om te krimp sedert wetgewing dit nie meer bevoordeel en beskerm nie. Verder smoor onderlinge verdeeldheid en partyskappe ook die Christelike kerk se stem van getuienis na die wêreld.

Die uitdaging vir die Christelike kerke van vandag is om 'n balans te vind. Aan die een kant kan die negatiewe invloede wat die bevoorregte posisie wat die Christelike geloof tot gevolg gehad het, nie ontken of afgemaak word nie. Aan die ander kant moet egter nie net hierop gefokus word nie, omdat dit die kerk in sy roeping en taak, hier en nou kan laat ontspoor. Die oes van medaljes is maar skraal, terwyl die letsels duidelik sigbaar is en in sommige gevalle steeds teer is. Dit is nodig dat die Christelike kerk selfondersoek sal doen. Met die resultate van die ondersoek in gedagte, moet die vraag eerder wees: Hoe kan Christene die sekulêre wêreld (Suid-Afrika) sodanig beïnvloed dat dit mense se lewens vir altyd positief sal verander? Watter rol kan die kerk speel om sulke veranderings teweeg te bring? 


\section{Geraadpleegde bronne}

AKENSON, D.H. 1992. God's peoples: covenant and land in South Africa, Israel and Ulster. New York: Cornell University Press.

ANC. 1996. www.anc.org.za/misc/nkosi.html\#hist Date of access: 28 Sept. 2006.

ANSGAR, F. 2002. Everything is worthwhile at the end? Christian funeral liturgy amidst ecclesial tradition and secular rites. Studia liturgica, 32(1):8-68.

ANSWERING ISLAM. 1999-2008. www.answeringislam.org/crusades.html Date of access: 5 Mrt. 2008.

BARNARD, A. 1935. Die groei en ontwikkeling van plattelandse onderwys (blanke) in Transvaal, 1836-1934. Pretoria: Universiteit van Pretoria. (Ongepubliseerde tesis.)

BBC NEWS: AFRICA. 2003. www.news.bbc.co.uk/2/low/africa/3314075.stm Date of access: 28 Sept. 2006.

BIBLICAL HISTORY TIMELINE. Ministry of Truth and Knowledge. www.biblicalhistorytimeline.com/313to609AD.htm Date of access: 4 Aug. 2006.

BOOYENS, B. 1970. Wesenskenmerke van die Afrikaner se identiteit. Handhaaf, 4:29-34, Aug.

BRADY, J.E. 1951. History of the church in South Africa: the Catholic Church and Southern Africa. Cape Town: Catholic Archdiocese of Cape Town.

BRYCE, J. [1897] 1900. Impressions of South Africa. New York: Macmillan.

CALPIN, G.H. 1944. There are no South Africans. London: Nelson.

CARRUTHERS, E.J. 1995. Game protection in the Transvaal 1846 to 1926. Johannesburg: Perskor.

CHIDESTER, D. 1992. Religions of South Africa. Londen: Routledge.

COETZEE, A. 1945. Die Afrikaner se volkskunde. (In Van den Heever, C.M. \& Pienaar, P. de V., reds. Kultuurgeskiedenis van die Afrikaner: die eerste beskrywing van die Boerevolkslewe in al sy vertakkinge, 1945-1950. Deel 1. Kaapstad: Nasionale Pers. p. 361-428.)

CROSS, M. 1999. Imagery of identity in S.A. education, 1880-1990. Durham: Carolina Academic Press.

DE KIEWIET, C.W. 1941. A history of South Africa: social and economic. London: Oxford University Press.

DE VAAL, J.B. 1939. Opvoeding in Schoemansdal 1948-1867. Historiese studies, 1(2):25-30.

DE VILLIERS, M. 1988. Idiome-woordeboek: verklarings met afsonderlike Afrikaanse en Engelse begripslyste. Kaapstad: Nasou.

ENGELBRECHT, B. 1980. The kingdom of God and its implications for all education. Journal of theology for Southern Africa, 33:7-15.

ERASMUS, J. 2005. Who are the people with "no religion"? (In Symington, J., ed. South African Christian handbook 2005/2006. Wellington: Lux Verbi.BM. p. 87-101.)

FAK BLÊRKAS. 2006. www.fak.org.za/blerkas/woorde/026.txt Datum van gebruik: 28 Sept. 2006.

GELDENHUYS, S. 2006. Is selfmoord sonde? www.lewensverryking.co.za/ artikels003.ups Datum van gebruik: 17 Okt. 2006.

GEYSER, A. 1980. The place of the Bible in religious education. Journal of theology for Southern Africa, 33:16-23. 
GILIOMEE, H. 2003. The Afrikaners: biography of a people. Cape Town: Tafelberg.

GREAT BRITAIN COLONIAL OFFICE. 1904 Census returns of British South Africa. London: HMSO.

GREEF, M. 2006. Trou - in of uit? Lig, Aug. www.lig.co.za Datum van gebruik: 29 Sept. 2006.

GROBBELAAR, P.W. 1974. Die Afrikaner en sy kultuur. Deel 1: Mens en land. Kaapstad: Tafelberg.

HARLEY, A. 2004. 2001 Census results. www.aldsa.org/survey/2001\% 20census.html Date of access: 31 Oct. 2006.

HAYES, S. 2006. AIC: Southern African Missiological society. www.geocities. com/Athens?Parthenon/8409/aic.htm Date of access: 13 Oct. 2006.

HILL, J. 2005. What has Christianity ever done for us? Oxford: Hudson.

HISTORY OF MUSLIMS IN SOUTH AFRICA. 2004. www.ummah.com Date of access: 10 Oct. 2006.

HOFMEYR, H.J. 1913. Union of South Africa: report of the Sunday Observance Commission appointed under government notice no. 1345 of 1911. Cape Town: Cape Times.

HOFMEYR, J.W. \& PILLAY, G.J., eds. 1994. A history of Christianity in South Africa. Vol. 1. Pretoria: HAUM.

JENKINS, E. 2004. Symbols of nationhood. Presidential address: 18 November 2003, Auden House Johannesburg. Johannesburg: South African Institute of Race Relations.

JOBY, C.R. 2007. Calvinism and the arts: a re-assessment. Leuven: Peeters.

JOHNSTONE, P.J. St. G., JOHNSTONE, R.J. \& MANDRYK, J. 2001. Operation world. Virginia: Donnelley.

JOOSTE, J.P. 1946. Die verhouding tussen kerk en staat aan die Kaap tot die helfte van die negentiende eeu. Bloemfontein: SACUM.

JORDAAN, A.M. 2004. Mites rondom Afrikaans. Pretoria: Universiteit van Pretoria. (Ongepubliseerde tesis.)

KRUGER, S.J.P. 1902. The memoirs of Paul Kruger. Vol. 1. London: Unwin.

LABUSCHAGNE, P. Die bestaan van wetenskaplike historiese gronde vir 'n naamsverandering. www.vryheidsfront.co.za/a/pretoria/dokumente/Pta NaamAfr.pdf Datum van gebruik: 30 Okt. 2006.

LIFE IN AMERICA. 2000. Why do Africans drop their English names when they come to America? www.africawired.com/discus/messages/19/99.html? 1091441078 Date of access: 28 Sept. 2006.

NATIONAL ANTHEM. 2007. www.info.gov.za/aboutgovt/symbols/anthem.htm Date of access: 25 Sept. 2008.

NDURU, M. 2006. Death penalty: calls for the return of capital punishment in South Africa. www.ipsnews.net/news.asp.idnews=33527 Date of access: 25 Sept. 2008.

NEL, F. 2002. Totsiens mossies. www.god-forum.co.za/kontreiafrikaans/ mossies.htm Datum van gebruik: 28 Sept. 2006.

NEWS24. 2007. Our hands are dirty ... www.news24.com Date of access: 20 Mar. 2008.

NG KERK. 1975. Human relations and the South African scene in the light of the Scriptures. Kaapstad: NG Kerkuitgewers.

NG KERK. 2006. Barmhartigheidsdienste. www.ngk.org.za Datum van gebruik: 21 Jan. 2008. 
NGANDEU, N. 2000. www.cameroon.net/showthread.php?t=93 Date of access: 28 Sept. 2006.

NIXON, J. 1880. Among the Boers. Cape Town: Juta.

OLIVER, E. 1998. Bybel ABC: dieselfde boek uit 'n ander hoek. Nelspruit: NHKA. (Ongepubliseerde Bybelstudiehandleiding.)

OLIVER, E. 2005. The impact of Christian education on the Zuid-Afrikaansche Republiek. Pretoria: University of South Africa. (Unpublished thesis.)

OLIVER, E. 2007. Die rol en taak van die kerk ten opsigte van begrafnisgebruike. Verbum et ecclesia, 28(2):558-579.

PAMA, C. 1960. Simbole van die Unie. Kaapstad: Maskew Miller.

PAMA, C. 1965. Lions and virgins: heraldic state symbols, coats-of-arms, flags, seals and other symbols of authority in South Africa 1487-1962. Cape Town: Human \& Rousseau.

POO, D. 2006. SA Post Office Stamps. E-pos aan olivee@unisa.ac.za.

PONT, A.D. 1968. 'n Oorsig van die algemene kerkgeskiedenis en die geskiedenis van die Nederduitsch Hervormde Kerk van Afrika. Pretoria: HAUM.

PRETORIUS, E. 2008. Moerdijk en die gedagte van die altaar. Pretoria: Voortrekkermonument.

ROSE, E.B. 1902. The truth about the Transvaal: a record of facts based upon twelve years residence in the country. London: Rose.

ROSSLEE, D.D. 1955. Sondagsheiliging in ons moderne samelewing. Bloemfontein: SACUM

SACC

see SOUTH AFRICAN COUNCIL OF CHURCHES

SCHMIDT, A.J. 2004. How Christianity changed the world. Grand Rapids: Zondervan.

SCHUTTE, J.H.T. 1943. Die kulturele eenwording van die Boere in die Republieke, 1854-1877. Pretoria: Universiteit van Pretoria. (Ongepubliseerde tesis.)

SOOKA, Y.L. 1993. A Hindu experience of religious freedom in the South African context. (In Kilian J., ed. Religious freedom in South Africa. Pretoria: Unisa. p. 82-92.)

SOUTH AFRICA. 2001. Religion by geographical areas for persons weighed. Sub-committee report: report of the census sub-committee to the South African Statistics Council on census 2001. www.statssa.gov.za/extract.htm Date of access: 4 Aug. 2006.

SOUTH AFRICA. HOUSE OF ASSEMBLY. 1950. Debates. Pretoria: Government Printer.

SOUTH AFRICAN COUNCIL OF CHURCHES. 2001. www.sacc.org.za Date of access: 24 Jan. 2008.

SOUTH AFRICAN MARRIAGES AND DIVORCES REPORT. 1915. Stats SA resource centre. www.statssa.gov.za Date of access: 3 Jul. 2006.

STATISTICS SOUTH AFRICA. 2004. Marriages and divorce 2004. www.statssa.gov.za Date of access: 3 Jul. 2006.

STUART, J. 1854. De Hollandsche Afrikanen en hunne Republieken in ZuidAfrika. Amsterdam: Tielkemeijer.

SWARAJ FOUNDATION. 2001. The counter renaissance: a publication by and for African youth. www.swaraj.org/counterrenmay.htm Date of access: 5 Mar. 2008. 
TRUTH AND RECONCILIATION COMMISSION. 1998. Register of reconciliation. www.doj.gov.za/trc/ror/page13.htm Date of access: 15 Aug. 2006.

UNION OF SOUTH AFRICA. 1915. Statistical year-book. No. 2: 1913-1914. Pretoria: HMSO.

VAN DER KOOI, P. 1999. Die ware betekenis van die calvinisme. Die kerkpad, 3(4):1. home.mweb.co.za/ke/kerkpad/julie99/calvinisme.html Datum van gebruik: 5 Mrt. 2008.

VAN DER VYVER, J.D. s.a. Die staatstaak ten opsigte van Sondagheiliging. Potchefstroom: PU vir $\mathrm{CHO}$. (Studiestuk 26: Instituut vir Bevordering van Calvinisme.)

VAN WYK, J.H. 1980. Die etiek van kans: 'n teologies-etiese besinning oor veral dobbelary, lotery en kansspeletjies. Potchefstroom: PU vir $\mathrm{CHO}$. (Wetenskaplike bydraes van die PU vir CHO: Reeks F1, IBCstudiestukke.)

VAN WYK, J.H. 1981. Sondagsport: wat sê die Bybel? Potchefstroom: Instituut vir Reformatoriese Studie.

VORSTER, N. 2006. Is selfmoord sonde? Kan iemand wat selfmoord gepleeg het, gered word? www.midweek.co.za Datum van gebruik: 17 Okt. 2006.

\section{Kernbegrippe:}

calvinisme

Christelike invloed op die regering

Christelike invloed op kultuur

Christelike invloed op wetgewing

Christendom in Suid-Afrika

historiese perspektief

Key concepts:

calvinism

Christian influence on culture

Christian influence on government

Christian influence on law

Christianity in South Africa

historical perspective 